\title{
EFFECT OF SOCIO-ECONOMIC CHARACTERISTICS OF GREENHOUSE FARMERS ON VEGETABLE PRODUCTION IN OGUN STATE, NIGERIA
}

\section{EFECTO DE LAS CARACTERÍSTICAS SOCIOECONÓMICAS DE LOS AGRICULTORES DE INVERNADEROS EN LA PRODUCCIÓN DE VERDURAS EN EL ESTADO DE OGUN, NIGERIA}

Wasiu Oyeleke Oyediran ${ }^{1,}{ }^{*}$, Ayodeji M. Omoare ${ }^{2}$, Adelayo A. Shobowale ${ }^{1}$, Adebesi O. Onabajo 3

1- Department of Agricultural Extension and Rural Development, Federal University of Agriculture, Abeokuta, Nigeria.

2- Department of Agricultural Education, Federal College of Education, Abeokuta, Ogun State, Nigeria.

3- Department of Animal Production, Olabisi Onabanjo University, Ayetoro Campus, Nigeria. Author for correspondence, email: oyediran_wasiu@yahoo.com

\section{ABSTRACT}

In Nigeria, vegetable production is adversely affected by climate change, pest and diseases attack and unfavourably environmental condition which have made resourceful farmers and government to embark on vegetable production under greenhouse technology. Hence, this study was conducted to assess socio-economic importance of greenhouse technology for sustainable vegetable production in Ogun State, Nigeria. The specific objective is to identify major limitations to the practice of greenhouse vegetable in the study area. One hundred and twenty (120) vegetable farmers were purposively selected for this study. Data were collected using well-structured interview guide and analyzed with descriptive statistics and chi-square analysis. The results showed that the respondents were $32-40$ years of age; predominantly male $(90.8 \%)$, and had formal education $(28.3 \%)$. Socio-economic importance of greenhouse technology includes increased yield (94.3\%), available supplies all the year round $(85.7 \%)$, and higher income generation $(75.7 \%)$. Paradoxically, greenhouse vegetable production has not been widely spread due to difficult to establish it by individuals and high cost of construction (98.3\%). So also, chi-square results showed that significant relationship existed between the major limitations and socio-economic importance of greenhouse technology at $p<0.05$ level of significance. This study recommends that cost of raw 
materials for constructing greenhouse should be subsidized by the Federal Government of Nigeria while wealthy individuals, farmers' groups and cooperative societies should invest in greenhouse technology for large scale vegetable farming.

Keywords: socio-economic, vegetable, greenhouse, technology, limitations, practice

\section{RESUMEN}

En Nigeria, la producción de hortalizas se ve afectada negativamente por el cambio climático, el ataque de plagas y enfermedades y las condiciones ambientales desfavorables que han hecho que los agricultores y el gobierno ingeniosos se embarquen en la producción de hortalizas con tecnología de invernadero. Por lo tanto, este estudio se realizó para evaluar la importancia socioeconómica de la tecnología de efecto invernadero para la producción sostenible de hortalizas en el estado de Ogun, Nigeria. El objetivo específico es identificar las principales limitaciones a la práctica de hortalizas de invernadero en el área de estudio. Ciento veinte (120) productores de hortalizas fueron seleccionados deliberadamente para este estudio. Los datos se recopilaron mediante una guía de entrevista bien estructurada y se analizaron con estadísticas descriptivas y análisis de chi-cuadrado. Los resultados mostraron que los encuestados tenían entre 32 y 40 años de edad; predominantemente masculino $(90.8 \%)$, y tenía educación formal (28.3\%). La importancia socioeconómica de la tecnología de efecto invernadero incluye un mayor rendimiento $(94.3 \%)$, suministros disponibles durante todo el año (85.7\%), y mayor generación de ingresos (75.7\%). Paradójicamente, la producción de hortalizas de invernadero no se ha extendido ampliamente debido a la dificultad de establecerla por parte de los individuos y el alto costo de construcción (98.3\%). Así también, los resultados de chi-cuadrado mostraron que existía una relación significativa entre las principales limitaciones y la importancia socioeconómica de la tecnología de invernadero con un nivel de significancia $p<0.05$. Este estudio recomienda que el gobierno federal de Nigeria subsidie el costo de las materias primas para la construcción del invernadero, mientras que las personas adineradas, los grupos de agricultores y las sociedades cooperativas deberían invertir en tecnología de invernadero para el cultivo de hortalizas a gran escala.

Palabras clave: socioeconómico, vegetal, invernadero, tecnología, limitaciones, práctica.

\section{INTRODUCTION}

Vegetable production has been a major agricultural activity in Nigeria for many decades and the crops are produced at both subsistence and commercial scale by rural farmers. The common vegetable cultivated in Nigeria includes tomatoes, okra, pepper, 
amaranthus, celosia, cochorus and so on (Giroh et al. 2008). Dawit et al.(2004) reported that the production of vegetable could be in the backyards for home consumption or in a large scale for both local and international markets. It is a good source of income, employment and food for rural households and people in the urban centres. It is very nutritive and usually consumed in the combination of traditional carbohydrate meal like eba, amala, pounded yam, semo and so on. Vegetable crops constitute 30 to 50 percent of iron and vitamin A in resource poor diet (Mofeke et al. 2003). It is however reported that the consumption of vegetables is generally lower in developing countries, $206 \mathrm{~g}$ per day per capita, compared to the recommendation of Food and Agriculture Organization of $75 \mathrm{~kg}$ per year due to shortage in supply during the dry season (Badmus and Yekini 2011); the production in the country is below the demand as the population continue increasing while demand for vegetables is increasing especially for export (Tsegay 2010). Hence, the country has not been able to meet its domestic requirements for vegetables and fruits. Report of 2009 and 2010 showed that Nigeria imported a total of 105,000 metric tonnes of tomato paste valued at over 16 billion to bridge the deficit gap between supply and demand in the country (Food and Agricultural Organization 2013). Despite the importance of vegetables, its production is usually carried out in the open field which exposed the crops to pest and diseases and vagaries of weather, and consequently lowers its yield, quality and supply for human consumption. To overcome the challenges of adverse climatic conditions and pest infestation on vegetable productivity, protective cultivation has been recommended for vegetable production (Dinham 2003). Greenhouse technology is one of the protective cultivation and it is the latest structure where the plants are grown under controlled or partially controlled environment resulting in higher yields than those that are under open conditions (Alvin 2001). It is used to protect the plants from the adverse climatic conditions such as wind, cold, precipitation, excessive radiation, extreme temperature, insects and diseases. It is also of vital importance to create an ideal micro climate around the plants. This is possible by erecting a greenhouse/glass house, where the environmental conditions are so modified that one can grow any plant in any place at any time by providing suitable environmental conditions with minimum labour. Vegetable production under protective structure reduces yield losses from insects, diseases, heavy rains and sunburn which results in higher productivity and returns per unit area (Oyediran 2016).

Vegetable crops are available all the year round in the market through the greenhouse technology thereby creating marketing and economic empowerment for the rural dwellers. It is against this background, and the need to increase vegetable production and its contributions to socio-economic of the vegetable farmers that this study becomes necessary. There is paucity of information and research on socio-economic importance of greenhouse technology for sustainable vegetable production; and also on the relationship between greenhouse technology and empowerment of the rural farmers. The available researches focused on greenhouse structure and its management (Hochmuth 2015); crop agronomy 
(Alvin 2001), cost, merits and demerits of raising crops in the greenhouse (Olivier 2001). This study was therefore carried out to assess socio-economic importance of greenhouse technology for sustainable vegetable production in Ogun State, Nigeria.

The specific objectives are to: 1) evaluate the socio-economic importance of greenhouse technology in the study area; and 2) identify major limitations to the practice of greenhouse vegetable in the study area. The hypothesis is there is no significant relationship between the farmers' socio-economic characteristics and major limitations to greenhouse technology.

\section{MATERIAL AND METHODS}

Description of study area: Ogun State is one of the six States in the southwest, Nigeria. The state was created in February $3^{\text {rd }}, 1976$. It is bounded in the west by Republic of Benin, bounded in the south by Lagos State and Atlantic Ocean, in the North by both Oyo and Osun States and in the East by Ondo State. The State lies between the latitudes $7^{\circ} 18^{\prime} \mathrm{N}$ and longitude $5^{0} 55^{\prime} \mathrm{E}$. It is situated within the tropics covering $16,409.29 \mathrm{~km}^{2}$ with a population of about 4,054,272 (National Population Commission (NPC 2006). Ogun State is heterogeneous state, inhabited predominantly by the Egba, Yewa, Ijebu, Remo, Awori and Egun who belong to the Yoruba ethnic group on the Africa Continents. The population of males in Ogun State is $1,847,243$ while the population of female is $1,880,855$ according to Nigeria Population Census final population release (NPC 2006). The state is approximately covering 1.9 percent (i.e. $16,762 \mathrm{~km}^{2}$ ) of Nigeria $923,219 \mathrm{~km}^{2}$ land areas, has bimodal rainfall pattern which reaches its peak in July and September; rainfall ranges from $13 \mathrm{~mm}$ to $197 \mathrm{~mm}$ per annum. The temperature was between $27.7^{\circ} \mathrm{C}$ and $29.1^{\circ} \mathrm{C}$ during the data collection. The state comprises of mostly agrarian communities which engages the farming activities of both males and females, in cash crops and food crops in order to meet the livelihood needs of the farmer, in addition to their foreign exchange. Most of the crops grown in Ogun State include cassava, rice, maize, melon, cotton, cocoyam, cocoa, yam, cowpea and vegetables (Oyediran 2016). Sampling technique and sample size: The study was carried out in Ogun State, Nigeria from January to March, 2018 during dry season vegetable farming. The two Local Government Areas purposively selected were Ewekoro and Odeda because there are greenhouse facilities in these areas. The greenhouse built in Owowo and Kotopo were selected for this study; ten greenhouses from Owowo and four greenhouses from Kotopo making fourteen greenhouses selected. Eighty vegetable farmers were randomly selected from 129 vegetable farmers in Owowo greenhouse while forty (40) vegetable farmers were selected from 63 vegetable farmers in Kotopo making 120 vegetable farmers selected from the two locations; this constituted the sample size for this study. 
Data Collection Method and Measurement of Variables: Interview guide was used for data collection. This instrument was subjected to content validity through the efforts of experts in the field of Agricultural Sciences. Items that lack clarity were instantly removed. For the reliability of the instrument, test re-test method was used at interval of two weeks with 25 vegetable farmers in Ijebu-Ode LGA. Reliability coefficients were estimated through Pearson Product Moment Correlation (PPMC). The instrument was termed reliable with reliability coefficients of 0.80 . Variables such as age and years of experience were measured at ratio level, educational qualification was measured at ordinal level and marital status was nominally measured. The socio-economic importance of greenhouse was conceptualized as Yes (1) and No (0). The limitations are ranked according to the frequency distribution. Descriptive statistics and chi-square were used to analyze the data.

\section{RESULTS AND DISCUSSION}

Personal characteristics of respondents: The results in Table 1 showed that $69.2 \%$ of the respondents were $32-40$ years of age while $17.5 \%$ were $41-50$ years and $8.3 \%$ were below 30 years of age. It was only very few $(5 \%)$ of the respondents that were above 51 years of age. The mean age of the respondents was 34.6 years. This depicts that the vegetable farmers are relative young, active and have agility to carry out farming activities. Oyediran et al. (2016) have mentioned that people who are young are more prone to risk taking than the old people hence, tends to be productive in agricultural sector. Most (90.8\%) of the respondents were male and the remaining $9.2 \%$ were female. It has been reported that men are predominantly engaged in farming activities in Sub-Saharan African due to its tedious nature while women carried out processing and marketing of agricultural produce (Odebode, 2007 and Oyediran et al. 2017). About 73.3\% were married, 14.2\% divorced and $12.5 \%$ were single. This is an indication that married category is higher and respondents in this category are responsible to provide food, clothes and shelter for the members of their households. Omoare et al. (2015) and Oyediran et al. (2016) explained that marriage is an institution that confers responsibilities on individuals that are involved to take care of their families and participate in other communities' activities. Results on education revealed that $17.5 \%$ of the respondents did not have formal education but more than half $(57.5 \%)$ had secondary education and $28.3 \%$ had tertiary education. Since majority $(85.8 \%)$ of the respondents had formal education it can be said that the vegetable farmers are literates. Education is very important for effective and efficient management of the greenhouse activities. Higher educational status of farmers accelerates information dissemination, learning and skill acquisition to develop, maintain and sustain greenhouse technology. The finding conforms to the position of Yahaya and Olajide (2002) that educational level influenced farmers' preference for printed materials and skills' acquisition in Nigeria. In a 
similar vein, more than half $(54.2 \%)$ of the respondents had spent 6 - 10 years in vegetable farming, $26.1 \%$ spent less than 5 years while $19.1 \%$ had spent more than 11 years. The mean farming experience was 7.6 years. This shows that vegetable farmers have put appreciable years into farming activities which can translate to better management of their farms. This finding agrees to report of Abiona (2010) that years of farming experience usually play a vital role in any farming enterprise.

Socio-economic importance of greenhouse technology: The results in Table 2 showed that $88.3 \%$ of the respondents affirmed that greenhouse technology provides job opportunity for the youth, and $81.6 \%$ indicated that it promotes groups formation among the farmers. The reason for engaging youths is to carry out some tedious operations like soil sterilization, nursery, transplanting and fertilizer application. It was also found that greenhouse technology facilitates cluster marketing $(72.5 \%)$ and contributes to rural development $(91.7 \%)$. These findings are possible since the greenhouses are usually constructed in a cluster pattern in order to easy distribution of farm inputs, sharing of agricultural resources and information and training of vegetable farmers.

Also, greenhouse technology has economic values as $94.1 \%$ of the respondents reported that it increases vegetable yield (94.3\%), supplies are all the year round (85.8\%) and the income is higher than conventional method (75.8\%). The increase recorded in yield, supplies and income by the respondents is as a result of quality output of vegetable under greenhouse technology. These findings are in line with report of Neave et al. (2011) that cabbage grown under nets reduced insect incidence and led to higher returns. Similar report by Shahak et al. (2004) revealed that shade netting determines the commercial value of crop, including rate of growth, yield, and product quality. Alvin (2001) opined that greenhouse tomato production offers interested growers an opportunity to produce a marketable product at times when supplies are low. It can be inferred that greenhouse technology has social and economic importance in vegetable farming and it contributes significantly to the livelihood sustainability of rural farmers in Nigeria.

Major limitations to the practice of greenhouse vegetable: The results in Table 3 showed that almost all (98.3\%) the respondents identified difficult to establish greenhouse technology by individuals due to high cost of construction as serious problem, $86.7 \%$ stated that it is expensive for the peasant vegetable farmers, and $85.8 \%$ mentioned the low awareness by the general public as the major limitation to the practice of greenhouse vegetable in the study area. The fact is that most peasant farmers in the rural areas could not have fund to construct greenhouse unless they form themselves into a cooperative group and pull their resources together for this technology. Some other problems identified include low quantity of vegetable produced (83.3\%), non-standardization in measurement for sales and marketing $(76.7 \%)$, high cost of maintenance $(70.8 \%)$, large scale farming is difficult to practice (69.2\%) and lack of technical know-how (55.8\%). Alvin (2001) emphasized the 
problem of technical know-how among the operators of greenhouse technology in Tennessee. In Nigeria, there is a serious problem of standardization for sales and marketing of agricultural produce and as such farmers are always at receiving end, price takers.

Table 1: Distribution of respondents based on personal characteristics ( $n=120)$

\begin{tabular}{lccc}
\hline Personal characteristics & Frequency & Percentages & Mean \\
\hline Age & 10 & 8.3 & \\
$\leq 30$ & 83 & 69.2 & 34.6 \\
$31-40$ & 21 & 17.5 & \\
$41-50$ & 06 & 5.0 & \\
Above 51 & & & \\
Gender & 109 & 90.8 & \\
Male & 11 & 9.2 & \\
Female & & & \\
Marital status & 15 & 12.5 & \\
Single & 88 & 73.3 & \\
Married & 17 & 14.2 & \\
Divorced & & & \\
Educational qualification & 06 & 5.0 & \\
No formal education & 11 & 9.2 & \\
Primary education & 69 & 57.5 & \\
Secondary education & 34 & 28.3 & \\
Tertiary education & & 26.7 & \\
Farming Experience (yrs.) & 32 & 54.2 & \\
$\leq 5$ & 65 & & \\
6 - 10 & 23 & & \\
$>11$ & & & \\
\hline
\end{tabular}

Source: Field Survey, 2018

Table 2: Socio-economic importance of greenhouse technology $(n=120)$

\begin{tabular}{lcc}
\hline Socio-economic importance & Yes (\%) & No (\%) \\
\hline Social & & \\
Greenhouse technology provides job opportunity for the youth & $106(88.3)$ & $14(11.7)$ \\
It promotes groups formation & $98(81.6)$ & $22(18.4)$ \\
It facilitates cluster marketing & $87(72.5)$ & $33(27.5)$ \\
Construction of greenhouse contributes to rural development & $110(91.7)$ & $10(8.3)$ \\
Economic & & \\
It increases yield & $113(94.1)$ & $07(5.9)$ \\
Vegetable are available all the year round & $103(85.8)$ & $17(14.2)$ \\
Higher income is realized & $91(75.8)$ & $29(24.2)$ \\
\hline
\end{tabular}

Source: Field Survey, 2018. Values in parenthesis are percentages 
Table 3: Distribution according to major limitations to the practice of greenhouse vegetable $(n=120)$

\begin{tabular}{lccc}
\hline Major limitations & Yes (\%) & No (\%) & Rank \\
\hline Lack of technical know-how & $67(55.8)$ & $53(44.2)$ & $8^{\text {th }}$ \\
Difficult to establish greenhouse technology by individuals due to & $118(98.3)$ & $02(1.7)$ & $1^{\text {st }}$ \\
its high construction cost & & & \\
Expensive for the peasant vegetable farmers & $104(86.7)$ & $16(13.3)$ & $2^{\text {nd }}$ \\
Low quantity produced & $100(83.3)$ & $20(16.7)$ & $4^{\text {th }}$ \\
Low awareness by the general public & $103(85.8)$ & $17(14.2)$ & $3^{\text {rd }}$ \\
Non-standardization in measurement for sales and marketing & $92(76.7)$ & $28(23.3)$ & $5^{\text {th }}$ \\
High cost of maintenance & $85(70.8)$ & $35(29.2)$ & $6^{\text {th }}$ \\
Large scale farming is difficult to practice & $83(69.2)$ & $37(30.8)$ & $7^{\text {th }}$ \\
\hline
\end{tabular}

Source: Field Survey, 2018. Values in parenthesis are percentages

Table 4: Relationship between the farmers' socio-economic characteristics and major limitations to greenhouse technology

\begin{tabular}{lcccc}
\hline Socio-economic Variables & $\mathrm{x}^{2}$ & $\mathrm{df}$ & $\mathrm{p}$-value & Decision \\
\hline Age & 17.61 & 3 & 0.001 & Significant \\
Gender & 5.73 & 1 & 0.017 & Significant \\
Marital status & 28.03 & 3 & 0.000 & Significant \\
Educational status & 55.08 & 2 & 0.000 & Significant \\
Farming experience & 68.63 & 2 & 0.000 & Significant \\
\hline
\end{tabular}

Source: Field Survey, 2018

$S$ - Significant at $p<0.05$ level of significance

Hypothesis testing: Test of relationship between the farmers' socio-economic characteristics and major limitations to greenhouse technology in the study area. Results of chi-square analysis in Table 4 revealed that significant relationship existed between age $\left(X^{2}\right.$ $=17.61, \mathrm{df}=3, \mathrm{p}=0.001)$, sex $\left(X^{2}=5.73, \mathrm{df}=1, \mathrm{p}=0.017\right)$, marital status $\left(X^{2}=28.03\right.$, $\mathrm{df}=3, \mathrm{p}=0.000)$, Educational status $\left(x^{2}=55.08, \mathrm{df}=2, \mathrm{p}=0.000\right)$, farming experience $\left(X^{2}=68.63, \mathrm{df}=2, \mathrm{p}=0.000\right)$ and limitations to the practice of greenhouse technology at $\mathrm{p}$ $<0.05$ level of significance. It can explained that these problems would affect older farmers than the younger farmers in the sense that younger farmers are risk takers and they are likely to adopt greenhouse technology compare to older farmers. The same thing with gender, men are courageous to confront these challenges and as such there will be more men than their counterpart women in greenhouse farming. Similarly, education is very important; it facilitates adoption of innovation among literate farmers than illiterate farmers. Experience also counts in vegetable farming; highly experienced farmers can maneuver some of these limitations and diversify to commercial greenhouse farming. Since all the variables 
are significance, it can be inferred that farmers' socio-economic characteristics have association with major limitations. Therefore, the null hypothesis that "there is no significant relationship between the farmers' socio-economic characteristics and major limitations to greenhouse technology" is rejected.

As conclusion, the study established that the respondents were relatively young and active, predominantly male, married, have formal education and wealth of experience in vegetable farming. Socio-economic benefits of greenhouse technology are opportunity of cluster marketing, rural development, increased yield, available supplies all the year round and higher income being realized than the conventional method. Meanwhile, there are major limitations which include difficult to establish greenhouse technology by individuals due to high cost of construction, expensive for the peasant vegetable farmers, and low awareness by the general public. Also, there is significant relationship between the major limitations and socio-economic importance of greenhouse technology at $p<0.05$ level of significance. From these findings, it is hereby recommended that cost of raw materials for constructing greenhouse should be subsidized by the Federal Government of Nigeria; wealthy individuals, farmers' groups and cooperative societies should invest in greenhouse technology for large scale vegetable farming; public awareness should be created through radio and television to encourage patronage; and regular training support should be given to the vegetable farmers by the extension agents. In addition, financial institutions should help farmers' groups through provision of affordable loans to enable them construct and expand greenhouse farming.

\section{REFERENCES}

Abiona, B.G. (2010). Comparative Analysis of integrated and non-Integrated fish farming in Ogun State, Nigeria. Unpublished Ph.D. Thesis, Department of Agricultural Extension and Rural Development, Federal University of Agriculture Abeokuta, pp. 43 - 44.

Alvin, D.R. (2001). Commercial Greenhouse tomato production. Agricultural Extension Service, The University of Tennessee.

Badmus, M.A. and Yekinni, T.O. (2011). Economic Analysis of Exotic Vegetable Production among Urban Fadama Women Farmers in Akinyele Local Government Area of Oyo State, Nigeria.International Journal of Agricultural Economics and Rural Development, 4(1): $19-24$.

Borguini, R.G. and Torres, E.A.F. (2009). Tomato and Tomato Products as Dietary Sources of Antioxidants. Food Reviews International. Philadelphia. Vol. 25, Iss. 4; p. 313-325.

Dawit, A., Abera, D., Lemma, D. and Chemdo, A. (2004). Domestic Vegetable Seed Production and Marketing. Research Report No 5. EARO, Ethiopia. 17p. 
Dinham, B., (2003). Growing Vegetables in Developing Countries for Local Urban Populations and Export Markets: Problems Confronting Small-Scale Producers. Pest Management Science, 59:575-582.

FAO, (2013). Fruits and Vegetables: An Overview onSocio-Economic and Technical Issues. Rome, Italy. www.fao.org

Giroh, D.Y., Umar, H.Y., Nudamatiya, A.B. and Moses, J. (2008). Analysis of Profitability and Technical Efficiency of Rubber Latex Production in Southern Nigeria: An Implication for Tree Crop Research: 10th Proceedings of the Annual National Conference of the National Association of Agricultural Economics (NAAE), held at 750 Seater Lecture Theatre Main Campus, University of Abuja, Nigeria. pp. 127-135.

Hochmuth, G.J. (2015). Production of greenhouse tomatoes. Greenhouse Vegetable Production Handbook, Vol. 3. 17p. Florida.

Mofeke, A.L.E., Ahmada, A. and Mudiane, O.J. (2003). Relationship between yield and seasonal water use for tomatoes, onions, and potatoes grown under fadama irrigation. Asset Series A. 3:35-46.

Neave, S.M., Kelly, G., and Furlong, M.J. (2011). Field evaluation of insect exclusion netting for the management of pests on cabbage (Brassica oleracea var. capitata) in the Solomon Islands. In: Abstracts from the Sixth International Workshop on Management of the Diamondback Moth and Other Crucifer Insect Pests, 21-25 March 2011, Kasetsart Unversity, Nakhon Pathom, Thailand. Publication No. 11-746. AVRDC -The World Vegetable Center, Taiwan. 101 pp.

NPC (National Population Center). 2006. Legal Notice of Publication of 2006 Census Final Result. Federal Republic of Nigeria Official gazette: Federal Capital Territory Abuja.

Odebode, S.O. (2007). Gender Participation of Melon Farmers in Ibarapa Area of Oyo State, Nigeria. Agricultural Journal, 2: 108-111.

Olivier de, V. (2001). Greenhouses and conservatories. Flammarion.

Omoare, A.M., Fakoya, E.O. and Oyediran, W.O. (2015). Value Addition of Sweet Potato (Ipomoea batatas L. Lam): Impending Factors on Household Food Security and Vitamin A Deficiency (VAD) In Southwest and Northcentral Nigeria. IOSR Journal of Agriculture and Veterinary Science (IOSR-JAVS), 8, Ver. II: 06-14

Oyediran, W.O., Omoare A.M. and Ajagbe, B.O. (2016). Factors affecting sustainability of melon (egusi) production in rural farming households of Southwest, Nigeria. American Journal of Agricultural Research, 1: 1 - 10.

Oyediran, W.O. (2016). Gender participation in tomato greenhouse technology empowerment scheme in Ogun State, Nigeria. International Journal of Research in Engineering and Social Sciences, 6: $17-28$. 
Oyediran, W.O., Omoare, A.M. and Osinowo, O.A. (2017). Contributive roles of sorghum production to food security and economic empowerment of rural farming households in Katsina State, Nigeria. Canadian Journal of Agriculture and Crops, 2: 42 - 49.

Shahak, Y., Gussakovsky, E.E., Gal, E., and Ganelevin, R. (2004). ColorNets: Crop protection and light-quality manipulation in one technology. Acta Hort. 659: 143-151.

Tsegay, L. (2010). High Value Agriculture in Eastern and Southern Africa: Increased Regional Trade: Opportunities and Issues, Ethiopian Horticulture Development Agency

Yahaya, M.K. and Olajide, B.R. (2002). Comparative Analysis of conventional and traditional media for the utilization of entertainment-education format for Agricultural Dissemination in Nigeria. Journal of Social Sciences, 7:1-7.

Received: $18^{\text {th }}$ June 2018. Accepted: 03 ${ }^{\text {th }}$ June 2019.

First distribution: 19 $9^{\text {th }}$ December 2019. Final publication: $13^{\text {th }}$ April 2020. 